\title{
NOTAS PARA EL ESTUDIO DE LA NATURALEZA JURÍDICA DE LA JURISDICCIÓN VOLUNTARIA (A PROPÓSITO DEL ANTEPROYECTO DE LEY DE JURISDICCIÓN VOLUNTARIA DE OCTUBRE DE 2005)
}

\author{
Juan Ramón LIÉBANA ORTIZ
}

PROFESOR TITULAR E.U. INTERINO DE DERECHO ADMINISTRATIVO

UNIVERSIDAD DE LA RIOJA

s $\quad$ u m a $\quad$ r i o

I. Objeto y justificación del estudio. II. Polémica doctrinal en torno a la naturaleza de la jurisdicción voluntaria. I. Posicionamiento jurisdiccionalista. 2. Posicionamiento administrativista. III. Doctrina del Tribunal Constitucional y del Tribunal Supremo. IV. Delimitación de la naturaleza jurídica de la jurisdicción voluntaria en el Anteproyecto de Ley de 2005: consideraciones críticas. I. Necesidad de una nueva regulación legal. 2. El concepto de potestad jurisdiccional en sentido amplio. 3. Superación del concepto y naturaleza jurídica. V. Conclusiones.

\section{Objeto y justificación del estudio.}

La jurisdicción voluntaria es un instituto jurídico de difícil definición ${ }^{\mathrm{I}}$ que se debe contemplar, en favor de una perfecta comprensión, como el resultado de una evolución histórica, configuradora y mediadora de su formulación teórica y desenvolvimiento real. Sólo desde la contraposición entre lo institucional y lo social puede descubrirse el contenido real de una institución en cada momento histórico, y sólo a través de un examen que contemple tales momentos puede intentarse esclarecer qué es y qué función cumple el instituto en la actualidad. Renunciar a este análisis histórico; esto es, desvincular la jurisdicción voluntaria de su naturaleza originaria y de su evolución posterior; supondría

\footnotetext{
${ }^{\mathrm{I}}$ Hasta tal punto es así, que algunos autores han abogado por la desaparición del concepto. En este sentido se pronuncian, por ejemplo, Prieto-CASTRO y FERRÁndiz, L., Cuestiones de Derecho Procesal, Madrid, Ed. Reus, I947, p. 26; y ALCALÁ-ZAMORA y CASTILlo, N., «Premisas para determinar la índole de la llamada jurisdicción voluntaria», en Studi in onore di Enrico Redenti, Vol. I, Dott. A. Giuffrè ed., Milano I95I, pp. 5-9.
} 
quedar anclados en el ámbito de la exégesis particularista actual, hacer absoluta, desde el punto de vista ideológico, su consideración vigente, obstaculizando, en consecuencia, el conocimiento de su objetivo y de su función.

Dentro del campo del Derecho Procesal, en el estudio de institutos procesales fundamentales, la visión y el método de trabajo historicista han sido ya utilizados por eminentes autores, tanto para la formulación de conceptos como para su comprensión de una forma inteligible ${ }^{2}$. Es éste, precisamente, el método que el Profesor FERNÁNDEZ DE BUJÁn sigue en la elaboración de su monografía La jurisdicción voluntaria ${ }^{3}$, en donde, para el análisis de las cuestiones medulares de la institución en su configuración actual, utiliza como referente la iurisdictio voluntaria romana, aparecida por primera vez en las Instituciones de MARCIANO ${ }^{4}$ y su evolución histórica posterior.

Pese a que la monografía citada constituye uno de los puntales doctrinales más modernos existentes en la materia, no ha lugar ahora a su recensión stricto sensu, y ello, cuando menos, por tres razones. En primer lugar, hemos de tener en cuenta la relativa distancia que nos separa de su publicación, casi cinco años atrás, y que hace que esta obra se encuentre suficientemente asentada entre la bibliografía procesalística española. En segundo lugar, ya en el año 2002 el Profesor AGUDO RUIZ se ocupó convenientemente de este menester, al comentar esta obra en una extensa recensión publicada en la revista Tribunales de Justicia5. En tercer lugar, la situación existente en el año 200 I se ha visto

\footnotetext{
${ }^{2}$ Entre otros, y sin ánimo de exhaustividad, cfr. FeneCH, M., «El Real Tribunal de la Acordada. Contribución al estudio de la Historia de las instituciones procesales de la América española. Siglo XVII», en FeneCh, M. y CARRERAS, J., Estudios de Derecho Procesal, Ed. Bosch, Barcelona I962, pp. I48-234; AlCALÁ-ZAMORA y CASTILlo, N., «Instituciones judiciales y procesales del Fuero de Cuenca», en Estudios de Teoría General e Historia del Proceso (1945-1972), Tomo II, Universidad Nacional Autónoma de México, I I reimp., México I992, pp. 333-4I4; MONTERo AROCA, J., «Bosquejo histórico de la conciliación hasta la Ley de Enjuiciamiento Civil de I855», en Estudios de Derecho Procesal, Ed. Bosch, Barcelona I98I, pp. I47-I88; FAIRÉN GUILlÉN, V., «El Consulado de la Lonja de Valencia: de proceso a arbitraje. Sus posibilidades», en Estudios de Derecho Procesal Civil, Penal y Constitucional, Tomo I, Editorial de Derecho Reunidas, Madrid I983, pp. I93-312; IDEM, El Tribunal de las Aguas de Valencia y su proceso, Caja de Ahorros de Valencia, $2^{\mathrm{a}}$ ed., Valencia I988, passim.

3 En concreto, La jurisdicción voluntaria, Ed. Civitas. Madrid 200I. Esta obra trae causa de anteriores investigaciones de su autor; en especial, de La jurisdicción voluntaria en Derecho Romano, Ed. Reus, Madrid I986. Hay que reseñar, aunque sólo sea brevemente, que las investigaciones del Profesor FERNÁNDEZ DE BUJÁN sobre la jurisdicción voluntaria, tanto en Derecho Romano como sobre la legislación vigente, son muy amplias; y, así, últimamente ha publicado, entre otros trabajos, «El problema de la naturaleza jurídica de la jurisdicción voluntaria a la luz de la experiencia histórica», en Revista General de Derecho Romano, núm. 5, Diciembre de 2005, pp. I-35; y, respecto de la legislación vigente, «La reforma de la jurisdicción voluntaria: problemas, interrogantes, soluciones», en Diario La Ley, núm. 6216, 23 de marzo de 2005, pp. I-9, también publicado en Revista General de Derecho Romano, núm. 5, Diciembre de 2005, pp. 36-67.

${ }^{4}$ Es generalizado el acuerdo en la doctrina romanística sobre el hecho de que la expresión iurisdictio voluntaria se menciona por primera vez en D.I.I6.2 pr.I. Vid., por todos, FERNÁNDEZ DE BUJÁN, A., La jurisdicción voluntaria en Derecho Romano, cit., especialmente pp. I8-27. Igualmente, en La jurisdicción voluntaria, cit., pp. 33 y $5 \mathrm{I}-56$. No obstante, se pronuncia en sentido contrario entre nosotros FAIRÉN GUILLÉN, V., en su comunicación publicada en I procedimenti in camera di consiglio e la tutela dei diritti, Dott. A. Giuffrè ed., Milano I99I, pp. I79 y I80. Para este autor, la jurisdicción voluntaria más bien parece ser obra mayor del Derecho intermedio. En concreto, entiende que «a la vista de la enorme cantidad de pruebas que nos dejaron los Glosadores, los Postglosadores y los Comentaristas y de su efectividad práctica, seguimos pensando que -aunque el fr. de MARCIANO no estuviese interpolado, lo que se discute- las claves actuales de la llamada "jurisdicción voluntaria" mejor deben de hallarse en aquellas doctrinas» (loc. cit., nota II).
}

${ }^{5}$ Cfr. Agudo Ruiz, A., «Recensión a la monografía "La jurisdicción voluntaria" de Antonio Fernández de Buján», en Tribunales de Justicia, núm. 8-9, 2002, pp. I09-I20. 
modificada en octubre de 2005 con la publicación por el Ministerio de Justicia de un borrador de Anteproyecto de Ley de Jurisdicción Voluntaria (en adelante ALJV), elaborado por la Sección de Derecho Mercantil de la Comisión General de Codificación; borrador que, como no podía ser de otra forma, ha de ser objeto de un estudio preferente en el presente trabajo.

No obstante, la mencionada monografía ha de servirnos de punto de partida para realizar unas primeras reflexiones en torno al estado de la cuestión objeto de estudio. En las páginas que siguen vamos a llevar a cabo una exposición crítica de la visión que sobre la naturaleza jurídica de los actos de jurisdicción voluntaria han sostenido los autores españoles que más atención han prestado a la institución, examinando especialmente la postura mantenida por FERNÁNDEZ DE BUJÁN a lo largo de estos últimos cinco años [infra II]. Asimismo examinaremos, siquiera sea brevemente, los pronunciamientos que sobre este particular han vertido el Tribunal Constitucional y el Tribunal Supremo [infra III], para pasar a abordar la postura contenida en el borrador de Anteproyecto de Ley de Jurisdicción Voluntaria [infra IV] y concluir el trabajo con unas breves conclusiones finales [infra V].

\section{Polémica doctrinal en torno a la naturaleza jurídica de la Jurisdicción Voluntaria.}

Junto a la existencia de importantes deficiencias en el régimen legal vigente de la jurisdicción voluntaria — como se verá, éste ha sido calificado de caótico, disperso, anacrónico y heterogéneo en sus contenidos (vid. infra apartado IV) - y a la imperiosa necesidad de una regulación completa y de nueva planta, ya anunciada por la LEC de 2000 , es posible constatar, de un primer acercamiento al tema que nos ocupa, la falta de un claro criterio delimitador de la naturaleza de la jurisdicción voluntaria.

Sin embargo, en nuestra opinión, como necesario requisito previo a la ardua tarea de legislar en esta materia, se debe determinar cuál sea la naturaleza jurídica de la institución; cuestión ésta sobre la que reina, según se ha llegado a afirmar ${ }^{6}$, el más completo caos en la doctrina procesalista. Es por ello que vamos a dedicar el presente epígrafe a analizar las corrientes de pensamiento existentes respecto de esta cuestión en la doctrina procesal española, las cuales bien pueden agruparse en torno a la consideración jurisdiccional o administrativa de los actos de jurisdicción voluntaria.

I. Posicionamiento jurisdiccionalista.

Siguiendo el método histórico que impregna toda la monografía citada, FERNÁNDEZ DE BUJÁN llega a concluir el carácter jurisdiccional de la jurisdicción voluntaria en Roma tanto en la época republicana como en la clásica, «si bien en esta última época se habría acentuado la finalidad negocial perseguida por las partes y se habrían atenuado las formalidades procesales de la legis actio en relación con las que era necesario observar en la época republicana» ${ }^{7}$. En la época posclásica, con la desaparición de la estructura procesal de

\footnotetext{
${ }^{6}$ Cfr. Garrido Falla, F., Palomar Olmeda, A., y Losada González, H., Tratado de Derecho Administrativo. Parte General, vol. I, Ed. Tecnos, I4ª ed., Madrid 2005, p. 46.

FERNÁNDEZ DE BUJÁN, A., La jurisdicción voluntaria, cit., p. 80; IDEM, «El problema de la naturaleza jurídica de la jurisdicción voluntaria a la luz de la experiencia histórica», loc. cit., p. 20. Vid., in extenso, del mismo autor Jurisdicción voluntaria en Derecho Romano, cit., pp. 44-48.
} 
la in iure cessio, se habría producido una disociación entre jurisdicción y proceso, y «la categoría de actos de jurisdicción voluntaria se aplicaría con la inclusión dentro de la misma de una serie de actuaciones, cuya conclusión se formalizará mediante decretum magistratual, dogmáticamente afines entre sí, que tendrían una naturaleza constitutiva, en ocasiones, declarativa o preventiva en otras, o de ius cogens, en cuanto que la ley exigiría la preceptiva intervención del magistrado». Así, las actuaciones de jurisdicción voluntaria negocial, en las que se tutelaban legítimos intereses privados, y todas aquellas materias dogmáticamente afines a éstas, en donde la intervención del magistrado no era legalmente preceptiva, se atribuyeron a los tabeliones, precedente remoto de los actuales notarios. Esta situación se vino a perpetuar durante toda la Edad Media europea e hizo que se difuminara el carácter jurisdiccional que poseían aquellos actos en un principio?.

Lejos de quedar en Roma el conjunto de sus consideraciones, tras exponer sucintamente los términos de la polémica doctrinal actual en torno a la naturaleza de la institución, FERNÁNDEZ DE BUJÁN procede a agrupar las actuaciones de jurisdicción voluntaria en dos modalidades: a) los supuestos que requieran la preceptiva intervención del Juez; los cuales, en su criterio, constituyen actuaciones de claro contenido jurisdiccional; y b) aquellos otros que cumplan básicamente una función legitimadora y de publicidad jurídica; en los cuales parece prevalecer, a su juicio, la naturaleza administrativa.

Si bien, en apoyo de su concepción sobre la naturaleza de esta institución, el autor se adhiere expresamente a la tesis mantenida últimamente por la Sentencia del Tribunal Supremo de 22 de mayo de 2000 (RJ 2000, 6275) —que tendremos ocasión de comentar infra en el apartado III de esta exposición-, lo cierto es que esta dicotomía parece ser una actualización de la diversa consideración que en el Derecho Romano posclásico tenían los actos de jurisdicción voluntaria en atención a la necesaria intervención del magistrado. De hecho, tras el establecimiento de la disyuntiva en atención a esta intervención, FERNÁNDEZ DE BUjÁN se centra exclusivamente en el fundamento de la por él mismo denominada «jurisdicción voluntaria judicial», faltando quizá, en nuestro criterio, una consideración más pormenorizada sobre su naturaleza, y dejando de lado, del mismo modo, cualquier consideración acerca de la naturaleza de aquellos actos de jurisdicción voluntaria que, en opinión de este autor ${ }^{\text {Io }}$, habrían de atribuirse a otros profesionales del Derecho.

Por su parte, a decir de DE LA OlIVA SANTOS se denomina jurisdicción voluntaria a «la autoridad y potestad ejercidas por el órgano jurisdiccional en cuya virtud, sin necesidad de proceso contradictorio entre diversos sujetos, se crean, modifican o extinguen estados y situaciones jurídicas, se acredita la existencia de hechos, se pretenden declaraciones a las que se anudan efectos jurídicos, se previene lo que al derecho de los sujetos jurídicos convenga o sea necesario y se llevan a cabo ciertos negocios jurídicos que requieren la intervención del Juez» ${ }^{\mathrm{II}}$. Pese a reconocer la controversia existente sobre este tema, RAMOS MÉNDEZ se pronuncia en el mismo sentido, al entender que a los actos de jurisdicción voluntaria hay que atribuirles verdadero carácter jurisdiccional dado que el fundamento de dichos actos se encuentra en el prestigio y las garantías que rodean la actuación

${ }^{8}$ FERNÁNDEZ DE BUJÁN, A., La jurisdicción voluntaria, cit., p. 82; IDEM, «El problema de la naturaleza jurídica de la jurisdicción voluntaria a la luz de la experiencia histórica», loc. cit., p. 2 I.

${ }^{9}$ Cfr. FERnÁndez de BujÁn, A., op. cit., pp. 82-96; IDEM, «El problema de la naturaleza jurídica de la jurisdicción voluntaria a la luz de la experiencia histórica», loc. cit., pp. 23-35.

${ }^{\text {Io }}$ Cfr. FERnÁNDEZ DE BUJÁN, A., La jurisdicción voluntaria, cit., pp. I5I-I6o.

II De la Oliva Santos, A. y Díez-Picazo Gimenez, I., Derecho Procesal Civil, Ed. Centro de Estudios Ramón Areces, $7^{\mathrm{a}}$ ed., Madrid 2002, p. 36. Igualmente, vid. Almagro Nosete, J., con Cortés Domínguez, V., Gimeno Sendra, V., y Moreno Catena, V., Derecho Procesal. Proceso Civil, Tomo I, Vol. II, Ed. Tirant lo Blanch, 6ª ed., Valencia I992, p. 539. 
jurisdiccional $^{12}$. Igualmente, ÁlvAREZ-CASTELLANOS defiende la tesis de que los procedimientos de jurisdicción voluntaria están perfectamente atribuidos, atendida su naturaleza jurídica, al órgano jurisdiccional ${ }^{13}$.

Así pues, el fundamento de dicha atribución se encuentra, precisamente, en la auctoritas y potestas jurídica de las que se halla investido el Juez, elementos necesarios a los efectos que se pretenden, y que llevan al sector de la doctrina que estamos viendo a mantener la naturaleza jurisdiccional de estos negocios jurídicos no contenciosos. RAMOs MÉNDEZ añade además otras notas que contribuyen a conferirles dicho carácter. Así, este autor considera que en las actuaciones de jurisdicción voluntaria existe processus iudicii, que los actos constitutivos deben al iudicium su existencia jurídica y, por último, que también en estos casos se produce el efecto de cosa juzgada, si bien limitado al concreto ámbito para el que están previstos dichos actos ${ }^{\mathrm{T}}$.

Por lo que se refiere a la autoridad y potestad con que cuenta el Juez, pese a ser un dato cierto, creemos que no es una condición en la que pueda fundamentarse exclusivamente una distinción de tanto calado. En su formulación clásica hay que entender por potestas el poder legalmente establecido o, en otros términos, la fuerza legítima; y por auctoritas el prestigio o reconocimiento social que opera por persuasión de la bondad de los dictados y veredictos del que la ostenta ${ }^{\text {t5 }}$. Aunque al tiempo de promulgarse la LEC decimonónica el hecho de que el Juez actuara investido de estas facultades pudo ser definitivo para calificar sus acciones como jurisdiccionales y, por tanto, para delimitar así sus atribuciones competenciales, en la actualidad estas facultades no pueden ser, en nuestra opinión, la clave de bóveda que separe lo jurisdiccional de lo administrativo por dos motivos.

De una parte, queda fuera de toda duda que los jueces y magistrados actúan investidos de auctoritas puesto que socialmente se les reconoce un determinado savoir-faire, pero esa misma facultad se le reconoce hoy a otros profesionales del Derecho como son los Notarios, los Registradores de la Propiedad e, incluso, a los funcionarios de la Administración pública.

De otra parte, el Juez actúa investido de potestas. Ésta supone una derivación de la soberanía que atribuye a su titular una posición de superioridad o de supremacía respecto de las personas que con él se relacionan, llevando insita una fuerza de mando capaz de vincular el comportamiento de los demás, acudiendo en caso necesario al uso de la fuerza. Sin embargo, esta potestad, atribuida a jueces y magistrados por la Constitución en su art. II7.3, también se atribuye a las Cortes Generales (art. 66 CE) cuando, por ejemplo, dicta una norma general que vincula a todos los ciudadanos y, a la Administración pública (arts. 97, I03 y Io6 CE) cuando se atribuye, por ejemplo, fuerza vinculante a los actos administrativos. Así, la noción de potestad denota una habilitación normativa para dictar cierto tipo de actos, si no siempre de interés público, sí de interés supraindividual.

\footnotetext{
${ }^{12}$ Ramos MéndeZ, F., Derecho Procesal Civil, Tomo II, Ed. Bosch, 5 a ed., Barcelona I992, p. I.294. Vid. igualmente GómEZ DE LiAÑO, F., El proceso civil, Ed. Forum, 2a ed., Oviedo I992, p. 566.

${ }^{13}$ A excepción del grupo de negocios correspondientes a registro y constatación de personas, cosas y actos, que —entiende - son puramente materia administrativa. ÁlvAREZ-CASTELLANOS RAEL, P., «El proceso de jurisdicción voluntaria», Revista de Derecho Procesal, I945, pp. 33I-353; especialmente pp. $342-343$.

${ }^{\mathrm{I} 4}$ Cfr. Ramos MéndeZ, F., Derecho Procesal Civil, cit., pp. I.294-I.295.

Is En esta última cualidad procedente del Derecho romano clásico, situa CARrerAS, J. («Las fronteras del juez», en FeneCH, M. y CARreras, J., Estudios de Derecho Procesal, Ed. Bosch, Barcelona I962, pp. IO9-IIO), siguiendo a D’ORS, la especificidad de la jurisdicción.
} 
Por tanto, en la actualidad no parece que puedan utilizarse la facultad de potestas que se atribuyen a los jueces para diferenciar netamente los actos de jurisdicción voluntaria de los actos administrativos, porque éstos también son emitidos por autoridades administrativas en ejercicio de potestades públicas conferidas por ley.

No obstante, cabría apuntar que la característica específica de la auctoritas judicial, que diferencia a los jueces y magistrados de los demás funcionarios públicos y operadores del Derecho, es su imparcialidad y su independencia (arts. II7.I, I24.I y I27.2 CE y I3 LOPJ) $y$, por tanto, que éste podría ser, en nuestro criterio, un importante argumento para fundamentar la atribución de los negocios de jurisdicción voluntaria al personal jurisdiccional. Así, mientras que la jurisdicción actúa esencialmente con «desinterés objetivo ${ }^{\mathrm{I} 6} \mathrm{y}$ la imparcialidad tiende a asegurar el desinterés subjetivo de la persona concreta del Juez, la imparcialidad del funcionario pretende asegurar también el desinterés subjetivo de la persona concreta (art. I03.3 CE), si bien ésta tiene que actuar «con objetividad al servicio de los intereses generales» (art. I03.I CE). Por su propia configuración constitucional, tal actuación siempre comporta la existencia de unos intereses políticos nacidos de mayorías electorales, por lo que no es posible hallar en ella el señalado desinterés objetivo. De la misma manera, la independencia judicial supone, por un lado, la sumisión exclusiva a la ley y, por otro, la no sumisión a otros tribunales superiores. Por su parte, los funcionarios, aunque deban sujetarse en su actuación a la ley y al Derecho, han de actuar, sin embargo, de acuerdo con el principio de jerarquía (art. I03.I CE). En definitiva, con esta concepción amplia de Administración de Justicia se evitaría el tener que forzar, como ocurre en Italia ${ }^{\mathrm{r7}}$, un significado extensivo de la potestad jurisdiccional, a fin de amparar constitucionalmente específicas funciones de jurisdicción voluntaria $-\mathrm{o}$, incluso, de instrucción penal - tradicionalmente encomendadas a jueces y magistrados. Sostener una visión reducida de la Administración de Justicia supone, en nuestra opinión, vaciar de fundamento constitucional las funciones jurisdiccionales en garantía de derechos que recoge el art. II7.4 CE.

En lo que respecta a la cosa juzgada, se debe tener en cuenta que la tendencia general en la doctrina es la contraria a la sostenida por RAMOS MÉNDEZ; esto es, la mayoría de los autores considera que a las resoluciones de jurisdicción voluntaria sólo se les pueden reconocer efectos de cosa juzgada formal ${ }^{18} \mathrm{y}$ no efectos de cosa juzgada material ${ }^{19}$, opinión mayoritaria a la que nos adherimos. Es ésta, asimismo, la postura que ha recogido el art. I8.I ALJV, al disponer que «lo resuelto en un expediente de jurisdicción voluntaria no tendrá efectos de cosa juzgada material, pudiendo promoverse sobre el mismo asunto proceso declarativo por el procedimiento que corresponda, en el cual podrá pedirse la confirmación, modificación o revocación de la resolución dictada en el expediente».

${ }^{16}$ Expresión utilizada para referirse a la imparcialidad por DE LA OlIVA SANTOS, A., con DíEZPicazo Giménez, I. y Vegas Torres, J., en Derecho Procesal. Introducción, Ed. Centro de Estudios Ramón Areces, Madrid 2000, p. 23.

${ }^{17}$ Cfr. MiCheli, G. A., «Significato e limiti della giurisdizione volontaria», Rivista di Diritto Processuale, I957, pp. 526-554.

${ }^{18}$ La cosa juzgada formal se predica de todas las resoluciones judiciales cuando contra ellas no se conoce recurso alguno o, concediéndose, no se interpone o formaliza en los plazos previstos, pasando la resolución, así, en autoridad de cosa juzgada (art. 207 LEC). Vid., asimismo, DE LA OLIVA SAntos, A. y DíEZ-PiCAzo Gimenez, I., Derecho Procesal Civil, cit., pp. 490-492.

${ }^{19}$ La cosa juzgada material consiste en una precisa y determinada fuerza de vincular, en otros procesos, a cualesquiera órganos jurisdiccionales respecto del contenido de esas resoluciones judiciales (de ordinario sentencias). Cfr. De la Oliva SAntos, A. y Díez-PiCAzo Gimenez, I., Derecho Procesal Civil, cit., pp. 492-493. 
Sin perjuicio de su estudio por diversos autores, uno de los que más ha estudiado el efecto de cosa juzgada en las resoluciones de jurisdicción voluntaria ha sido el italiano AlLORIO $^{20}$. Este autor utiliza la cosa juzgada como nota diferencial de la jurisdicción en contraposición a la actividad administrativa. A su juicio, la cosa juzgada es una prerrogativa vinculada exclusivamente a los actos que sean el resultado final de un proceso de declaración de certeza, porque están dotados de una solemnidad, complejidad y gradualidad que justifican ese efecto de inmutabilidad de la resolución. Así, según concluye, «la "jurisdicción" voluntaria es actividad administrativa, esto es, desprovista de cosa juzgada, por ser el resultado de un procedimiento no idóneo para justificar este último efecto, pero asignada, en cuando a la competencia, a órganos habitualmente jurisdiccionales, es decir, que normalmente cumplen una actividad jurisdiccional en sentido propio, productora de la cosa juzgada ${ }^{21}$.

Ahora bien, esta tesis sostenida por ALLORIO puede hacer surgir algunas dudas. Así, podría replicarse, aunque sin demasiado fundamento, que, formalmente, un acto administrativo no recurrido en tiempo y forma deviene firme y que, materialmente, la Administración pública no es siempre libre de venir sobre sus propias decisiones, especialmente cuando se trata de actos declarativos de derecho. Si de la fuerza de cosa juzgada se quieren hacer derivar elementales exigencias de seguridad jurídica, ésta no se puede desconocer tampoco en la actuación administrativa. Asimismo, algunos autores han sostenido que la cosa juzgada material no sólo falta en los procedimientos de jurisdicción voluntaria, sino también, por ejemplo, en las medidas cautelares ${ }^{22}$,dada su naturaleza esencialmente instrumental y su consustancial provisionalidad. De la misma manera, constituyen excepción, en cuanto a la producción de cosa juzgada material, las sentencias firmes sobre el fondo que recaen en los procesos llamados sumarios -entendiendo por tales aquéllos en que, debido a la limitación legal de los actos de alegación y prueba de las partes, la tutela jurisdiccional que se proporciona está sujeta a los resultados de una eventual apertura posterior de procesos plenarios, con plenas posibilidades de alegación y prueba $^{23}$-, y ello por disposición legal expresa que, con carácter general, realiza el art. 447.2 a 4 LEC.

De estos ejemplos tomados del Derecho positivo ha de concluirse que la cosa juzgada no es el conjunto de todos los efectos derivados de cualquier resolución que enjuicia un asunto. En consecuencia, se ha llegado a sostener que la cosa juzgada no pertenece a la esencia del juicio jurisdiccional ${ }^{24} \mathrm{y}$, por tanto, no podría ser alegado como elemento de distinción de la Jurisdicción frente a la Administración.

${ }^{2 \circ}$ Allorio, E., «Ensayo polémico sobre la “jurisdicción” voluntaria», en Problemas de Derecho Procesal (trad. Sentis Melendo), Tomo II, Ed. EJEA, Buenos Aires I963, pp. 3-46; IDEM, «Nuevas reflexiones críticas en tema de jurisdicción y cosa juzgada», en Problemas de Derecho Procesal, cit., pp. 5I-I28. En esta misma obra, además, tiene dos trabajos dedicados al estudio de la jurisdicción voluntaria: «Naturaleza de la cosa juzgada», pp. I29-164 y «Crítica de la teoría de la cosa juzgada implícita», pp. I65-I75.

${ }^{2 \pi}$ AlLORIO, E., «Ensayo polémico sobre la “jurisdicción” voluntaria», cit., p. 30.

${ }^{22}$ Cfr. Gimeno Gamarra, R., «Ensayo de una teoría general sobre la jurisdicción voluntaria», en Anuario de Derecho Civil, I953, p. 8 y DE LA Oliva SANTOS, A., Objeto del proceso y cosa juzgada en el proceso civil, Ed. Civitas, Madrid 2005, pp. I24-I25.

${ }^{23}$ De la Oliva Santos, A., Sobre la cosa juzgada, Ed. Centro de Estudios Ramón Areces, Madrid I991, pp. 36-37.

${ }^{24}$ Cfr. De LA Oliva SAnTOS, A., Objeto del proceso y cosa juzgada en el proceso civil, cit., p. I39. 


\section{Posicionamiento administrativista.}

Contrariamente a lo señalado hasta este momento, la opinión dominante entre la doctrina considera la jurisdicción voluntaria como una actividad administrativa. Así, para GUASP la concepción que delimita las actividades del Estado en atención a los órganos que las desempeñan no es suficiente para justificar que la institución sobre la que estamos reflexionando esté en manos de los tribunales y sea, por tanto, verdadera jurisdicción. Para él se trata de una actividad típicamente administrativa, aunque por el tipo de relaciones jurídicas sobre las que incide se trate de «administración judicial del Derecho privado». Según este autor, la naturaleza jurídica de tal jurisdicción hay que buscarla en el campo de la Administración porque «siendo administración cualquier actividad de realización de los fines de interés general, distinta tan sólo de la actividad legislativa y la actividad procesal, no queda otro cauce dentro de las figuras del Derecho público, al que la jurisdicción voluntaria indudablemente pertenece, dada la presencia en ella de un órgano del Estado, que atribuirla un contenido estrictamente administrativo» ${ }^{25}$. Así, en opinión de este autor, las disposiciones contenidas en el Libro III de la LEC I88I no son jurisdicción porque ésta no es otra cosa que «la función específica estatal por la cual el Poder Público satisface pretensiones» ${ }^{26} \mathrm{y}$ en aquéllas no se da tal satisfacción.

Ahora bien, la identificación de lo procesal con lo jurisdiccional, si bien no resulta arbitraria, sí que está todavía por demostrar ${ }^{27}$. Por una parte, si la jurisdicción es sólo función procesal, entonces el reajuste de competencias entre lo que actualmente pertenece al Derecho Administrativo y al Derecho Procesal no se terminaría con el traslado de la jurisdicción voluntaria a la primera de dichas disciplinas, sino que exigiría, además, que una parte importante de la actividad administrativa pasase a ser objeto del Derecho Procesal. Si la esencia del proceso consiste en una función de «satisfacción de pretensiones» entonces, siguiendo a GARRIDO FALLA, no podría negarse el carácter procesal de la actividad desplegada por la Administración pública al resolver, por ejemplo, un recurso de alzada impugnando la adjudicación de una plaza de funcionario público por entender el recurrente que es titular de un derecho preferente ${ }^{28}$. Por otra parte, al conceptuar la jurisdicción voluntaria como actividad administrativa del Derecho privado se desconoce que, aunque el Juez no resuelva efectivamente sobre las pretensiones de un particular respecto de otro, la resolución que éste dicte condiciona tanto las posibles pretensiones procesales que en el futuro pueda esgrimir el interesado como las que puedan esgrimirse frente a él.

${ }^{25}$ Guasp Delgado, J., Derecho Procesal Civil, Madrid, Reus, I956, p. I.647.

${ }^{26}$ Guasp Delgado, J. y Aragoneses Alonso, P., Derecho Procesal Civil, Tomo I, Madrid, Civitas, $7^{a}$ ed., 2004, p. 93. Subraya el autor que «para obtener una noción precisa de la función jurisdiccional hay que renunciar a toda idea que no parta de la congruencia que existe entre Jurisdicción y proceso, pues ambos conceptos son correlativos y cualquiera de ellos implica necesariamente el otro» (p. 94).

${ }^{27}$ No obstante, nos parece de interés - por lo clarificador- recoger aquí las palabras de MONTERO ARoCA, J., Derecho Jurisdiccional (con Gómez Colomer, J. L., Montón REDOndo, A. y BARONA Vilar, S.), Vol. I (Parte general), Tirant lo Blanch, I4 ${ }^{a}$ ed., Valencia 2005, al decir: «si se trata de identificar a una rama jurídica atendiendo a su concepto principal, que es el poder judicial o jurisdicción, y no a un concepto subordinado, que es el proceso, dígase de una vez: Derecho jurisdiccional» (p. 2I).

${ }^{28}$ GARRIDo FAlLA, F., «Sobre el Derecho administrativo y sus ideas cardinales», en Revista de Administración Pública, núm. 7, I952, pp. II-50. La tesis que el autor formula en este artículo es que el objeto del Derecho administrativo lo constituye la Administración en sentido subjetivo —-más que en sentido objetivo-; esto es, un tratamiento de todas las funciones ejercitadas por las autoridades administrativas y no de las funciones de índole administrativa atribuidas a cualquier autoridad (p. I2).

Redur 3 / año 2005 
Por su parte, GIMENo GAMARRA sostiene que, aunque presente ciertos rasgos o características que la diferencian del resto de la actividad administrativa, no hay posibilidad de considerar la jurisdicción voluntaria como una función especial del Estado distinta de la Jurisdicción y la Administración, sino que «ha de ser considerada como una función administrativa» ${ }^{29}$. En su opinión, la finalidad de la institución es, de nuevo, la administración pública del Derecho privado, pero especificando que la autoridad judicial opera a fin de integrar la capacidad deficiente o a fin de reparar la situación de peligro de los interesados. En palabras del autor, «la finalidad de proteger los derechos privados es lo que diferencia la jurisdicción voluntaria de la generalidad de los actos administrativos, ya que éstos tienden al cumplimiento de fines de interés general, y si a veces protegen también los derechos de los particulares, lo hacen de modo indirecto, sin que sea esa su finalidad específica, como lo es de la jurisdicción voluntaria» $»^{30}$.

Junto a las consideraciones ya realizadas en torno a la concepción de la jurisdicción voluntaria como administración pública del Derecho privado, considerar que ésta es una actividad administrativa porque en ella el Juez no actúa supra partes - por encima de los derechos a proteger-, sino situado en la misma línea de intereses que se traten de proteger en cada caso, supone, en primer lugar, desconocer la imparcialidad objetiva con que ha de actuar en todo momento la Administración pública (art. IO3.I CE). Así, a modo de ejemplo, el Jurado Provincial de Expropiación Forzosa, órgano de estricta naturaleza administrativa, encargado de la composición de las posiciones encontradas de expropiado y beneficiario, actúa supra partes - la Administración expropiante busca el cumplimiento de la legalidad- en la determinación del justo precio expropiatorio. En segundo lugar, el interés público y el privado coexisten en todo acto jurisdiccional, sin que sea posible su graduación respectiva. Así, la mayoría de los actos de jurisdicción voluntaria están impregnados, en efecto, de un interés público predominante, que impide dar plenos efectos a los actos realizados por los particulares sin intervención de la autoridad pública, sea o no judicial.

Siguiendo expresamente la opinión de WACH, PRIETO-CASTRO conceptúa la jurisdicción voluntaria como una actividad ejecutiva; o, en otros términos, como una actividad administrativa. En concreto, afirma que «la jurisdicción voluntaria es una actividad ejecutiva, realizada por órganos judiciales o no judiciales, encaminada a tutelar el orden jurídico mediante la constitución, desenvolvimiento o modificación de estados y relaciones jurídicas con carácter general» ${ }^{3 \mathrm{I}}$. En su opinión, esta actividad, por tanto, no puede ser consecuencia del ejercicio de una acción encaminada a lograr la realización del derecho objetivo porque sus resoluciones son variables y carecen de fuerza de cosa juzgada irrevocable. Consecuentemente con ello, enfrentado con el problema de las acciones constitutivas, resuelve que éstas, al existir contienda y pretenderse un derecho frente a alguien, no son jurisdicción voluntaria.

Sin embargo, esta teoría choca con la existencia de toda una serie de actos de jurisdicción voluntaria de carácter constitutivo ${ }^{32}$, acerca de cuales el autor no se pronuncia

${ }^{29}$ Gimeno Gamarra, R., «Ensayo de una teoría general sobre la jurisdicción voluntaria», op. cit., p. I9.

${ }^{30}$ Gimeno Gamarra, R., Loc. cit., p. il.

${ }^{3}$ Cfr. Prieto-Castro y Ferrándiz, L., Cuestiones de Derecho Procesal, cit., p. 277.

${ }^{32}$ Así, por ejemplo, el acogimiento (art. I.828 LEC I88I y arts. 58 y 69 ALJV), la adopción (arts. I.829 a I.832 LEC I88I y arts. 6067 ALJV), el nombramiento de tutores (arts. I.833 a I.840 LEC I88I y arts. 80 a 89 ALJV), la enajenación de bienes de menores o incapaces (arts. 2.0II a 2.030 LEC I88I y arts. Io० a IO7 ALJV), la ausencia y la declaración de fallecimiento (arts. 2.03I a 2.047 LEC I88I y arts. I08 a II9 ALJV), la calificación y la liquidación de averías (arts. 2.I3I a 2.I46 LEC I88I y arts. 
pero que, siguiendo su construcción teórica, habría que considerar de naturaleza contenciosa. Además, no tendría sentido, conforme a dicha tesis, que la tramitación y resolución de la adopción internacional se considere jurisdicción voluntaria (ex arts. 9.5 CC y $67 \mathrm{ALJV})$

Por último, a decir de PRIETO-CASTRO, en atención a de la clasificación de los negocios contenidos en el Libro III de la LEC i88I en judiciales, notariales y registrales no es posible concluir que su propia argumentación considere toda la jurisdicción voluntaria como una función administrativa exclusivamente ${ }^{33}$. Por nuestra parte, no obstante, entendemos que el hecho de atribuir el conocimiento de determinados actos de esta naturaleza a los órganos judiciales no muta su naturaleza jurídica; no olvidemos que tales órganos podrán conocer de aquéllas otras cuestiones - no jurisdiccionales- que en garantía de cualquier derecho les sean atribuidas por la ley (art. II7.4 CE).

Con el objetivo de determinar su naturaleza jurídica, SERRA DOMínGUEZ ${ }^{34}$ parte del examen de los supuestos de jurisdicción voluntaria contenidos en el Derecho positivo, procediendo a clasificarlos en cuatro apartados: a) actos constitutivos (que pueden tener carácter necesario o supletorio de lo que hubieran podido realizar los interesados); b) actos homologadores; c) actos de mera documentación; y d) actos de simple presencia. En los actos contenidos en los tres últimos grupos no se desarrollaría actividad jurisdiccional alguna, por lo que la intervención del Juez sería simplemente administrativa, de modo que su actuación podría asignarse, para los actos homologadores, a los notarios, y, para el resto de actos, a otros funcionarios públicos. Mayores problemas plantea la determinación de la naturaleza de los actos de jurisdicción voluntaria de efectos constitutivos, habida cuenta de su gran similitud con las sentencias constitutivas necesarias, cuyos efectos jurídicos sólo pueden lograrse a través de la actuación judicial; actuación insustituible por un acuerdo entre partes. No obstante tal similitud, en palabras de dicho autor «la especialidad de las sentencias constitutivas necesarias no depende de la jurisdicción, sino del contenido del derecho, no susceptible de disposición» ${ }^{35}$. Así pues, los actos de efectos constitutivos no constituyen, en su criterio, auténtica jurisdicción, ya que la necesaria intervención del Juez, no sustituible por el consentimiento de las partes, no es consecuencia del carácter jurisdiccional de tales actos, sino del contenido de la declaración que se solicita del órgano jurisdiccional; es decir, del carácter indisponible de los derechos sobre los que versa.

Por otro lado, para SERRA DOMÍNGUEZ carece de relevancia a qué órgano estén atribuidos los actos de jurisdicción voluntaria, ya que lo realmente importante es la determinación de cuándo unas funciones son jurisdiccionales y cuándo son administrativas. Es por ello que — termina argumentando- «mientras la jurisdicción existe independientemente del poder estatal ${ }^{36}$, los actos de jurisdicción voluntaria —incluidos los

267 a 280 ALJV) o la enajenación de efectos comerciales o mercantiles (art. 2.I6I LEC I88I y arts. 284 y 285 ALJV).

${ }^{33}$ Prieto-CAStro y Ferrándiz, L., Cuestiones de Derecho Procesal, cit., p. 280 y

${ }^{34}$ Serra Domínguez, M., «Naturaleza jurídica de la jurisdicción voluntaria», en Estudios de Derecho Procesal, Ed. Ariel, Barcelona i969, pp. 619-670.

${ }^{35}$ Cfr. Serra Domínguez, M., «Naturaleza jurídica...», cit., p. 636 .

${ }^{36}$ Entendiendo por jurisdicción «la determinación irrevocable del derecho en un caso concreto, seguida, en su caso, por su actuación práctica». SERRA DOMÍNGUEZ, M., «Jurisdicción», en Estudios de Derecho Procesal, cit., p. 5o; dónde el autor da un concepto absoluto de la jurisdicción. No obstante, al prescindir de la consideración de la jurisdicción como potestad del Estado se llega a un concepto que, aunque cierto, es muy poco preciso jurídicamente y muy poco concreto desde el punto de vista político. Además, algún autor ha dicho que «el no referir hoy la jurisdicción al Estado supone negar la realidad hasta el extremo de llegar a una noción prácticamente inútil». Cfr. MONTERO AROCA, J., 
constitutivos - no pueden subsistir, como actos con relevancia jurídica propia, sin la intervención del Estado » ${ }^{37}$ y así, de conformidad con el criterio definidor de la jurisdicción, que, para este autor, es la cosa juzgada, estos actos tienen una naturaleza jurídica administrativa.

A pesar de ser cierto que cuando las resoluciones de jurisdicción voluntaria adquieren el carácter de definitivas -bien porque los interesados no las recurran, bien porque haya pasado el plazo para hacerlo- son invariables (art. I.8I8 párrafo $2^{\circ}$ LEC I88I y argumento a contrario ex art. I8. I ALJV), sin embargo, es incuestionable que la ausencia de cosa juzgada constituye una de sus características fundamentales de su eficacia (arts. I.8ı8 LEC I88I y i8.I ALJV). Este es un argumento de peso para sostener la naturaleza jurídicoadministrativa de la jurisdicción voluntaria sobre el que, por exigencia de la configuración del presente trabajo, no nos extenderemos en este estudio.

\section{Doctrina del Tribunal Constitucional y del Tribunal Supremo.}

Si bien son escasos los pronunciamientos realizados por el máximo intérprete de la Constitución sobre la materia que venimos estudiando, lo cierto es que en una temprana sentencia, la I3/I98I, de 22 de abril, el Tribunal Constitucional vino a afirmar que «las variadas tesis formuladas por la doctrina, de un lado, sobre la naturaleza de esta jurisdicción voluntaria - desde una verdadera jurisdicción hasta una administración de derecho privado atribuida por razones históricas a órganos judiciales - y la diversidad, desde otro lado, de los supuestos contemplados en el Libro III de la LEC (de I88I), nos obliga a no sentar conclusiones generales sobre la necesidad o no de intervención de quienes puedan considerarse afectados en sus derechos por actos de jurisdicción voluntaria a la luz del artículo 24 de la Constitución. Será necesario, por el contrario, descender a los casos particulares para verlos a la luz del texto constitucional» (FJ $\left.3^{\mathrm{a}}\right)$. Esta doctrina de la consideración casuística de la naturaleza de los actos de jurisdicción voluntaria se ha visto reiterada en varias sentencias posteriores ${ }^{38}$.

Dejando a un lado alguna que otra sentencia referida a la indefensión en el marco de los procedimientos de esta naturaleza ${ }^{39}$, el Tribunal Constitucional ha tenido la oportunidad de pronunciarse sobre la materia que ahora interesa en supuestos particulares de los regulados en el Libro III de la LEC de I88I. En este sentido, con respecto a los procedimientos de adopción y acogimiento de menores, ha afirmado que «la función encomendada en estos casos al Juez no es la de juzgar y ejecutar lo juzgado (art. II7.3 CE),

Derecho Jurisdiccional (con Gómez Colomer, J. L., Montón Redondo, A. y BARonA Vilar, S.), Vol. I (Parte general), cit., p. 37.

${ }^{37}$ Serra DomíngueZ, M., «Naturaleza jurídica de la jurisdicción voluntaria», cit., p. 638.

$3^{8}$ Entre otras, SSTC 76/1990, de 26 de abril (FJ 6\%), 298/1993, de 18 de octubre (FJ 6\%), I87/I996, de 25 de noviembre (FJ $2^{\circ}$ ) y II4/I997, de 16 de junio (FJ $3^{\circ}$ ).

${ }^{39}$ Concretamente, el Tribunal Constitucional ha advertido que el art. 24 CE «no impone cauces procesales determinados, siempre que se respeten las garantías esenciales para proteger judicialmente los derechos e intereses legítimos de los justiciables (SSTC II/ı982, I/I987, 43/I987, I60/I99I). Lo fundamental desde la óptica constitucional es apreciar si en las circunstancias del concreto proceso seguido el titular del derecho fundamental ha disfrutado de una posibilidad real de defender sus derechos e intereses legítimos mediante los medios de alegación y de prueba suficientes, cuando se actúa con la diligencia procesal razonable (SSTC 4/1982 y I4/I992)» (STC I24/2002, de 20 de mayo [FJ $4^{\circ}$ ]). En el mismo sentido, SSTC 76/1990, de 26 de abril $\left(F^{\circ} 6^{\circ}\right)$, 298/I993, de I8 de octubre (FJ 6 ${ }^{\circ}$ ) y II4/I997, de I6 de junio (FJ $2^{\circ}$ ). 
sino que, al ser concebida al modo de la jurisdicción voluntaria, ha de incluirse en las funciones que, de acuerdo con el art. II7.4 CE, puede atribuirle expresamente la Ley en garantía de cualquier derecho» (SSTC 93/1983, de 8 de noviembre [FJ $3^{\circ}$ ] y I24/2002, de 20 de mayo $\left[\mathrm{FJ} 4^{\circ}\right]$ ). Igualmente, a decir del Alto Tribunal, los procedimientos de homologación civil de las resoluciones y decisiones eclesiásticas sobre matrimonio canónico rato y no consumado, «al modo de la jurisdicción voluntaria, responden a una actividad de constatación encomendada al Juez civil que ha de incluirse entre las funciones que, de acuerdo con el art. II7.4 de la Constitución, puede atribuir la ley expresamente al Juez en garantía de cualquier derecho» (SSTC 93/1983, de 8 de noviembre [FJ 3] y 328/1993, de 8 de noviembre $\left[\mathrm{FJ}^{\circ}\right]$ ).

Como se puede apreciar, pese a no entrar a enjuiciar abiertamente la naturaleza de la jurisdicción voluntaria, el Tribunal Constitucional se muestra partidario de residenciar en el art. II7.4 CE el fundamento constitucional de los negocios inter volentes de los que ha podido conocer, explicitando además que «en estos asuntos el Juez no juzga y hace ejecutar lo juzgado», lo que es tanto como decir que éste no ejerce la potestad jurisdiccional al conocer de aquellos negocios. En consonancia con la opinión mayoritaria de la doctrina española, favorable a la inclusión de estos negocios en el marco del precepto constitucional citado $^{40}$, esta postura proporciona un poderoso argumento para mantener el carácter no jurisdiccional o, en términos positivos, administrativo de la jurisdicción voluntaria.

Por su parte, con el examen de las sentencias en las que se ha pronunciado el Tribunal Supremo desde $1980^{4 \mathrm{x}}$ en materia de jurisdicción voluntaria, puede apreciarse que éste nunca ha tomado partido sobre su discutida naturaleza jurídica, sino que, por el contrario, se ha limitado a perfilar las características de los actos, de acuerdo con su regulación legal de carácter decimonónico. No obstante, a partir del cambio de siglo, puede hallarse alguna sentencia en la que se sostiene una postura implícita acerca de la naturaleza de la institución, que resulta, en nuestro criterio, diametralmente opuesta a la mantenida por el Tribunal Constitucional.

En efecto, en su sentencia de 22 de mayo de 2000 (RJ 2000, 6275), el Tribunal Supremo declara rotundamente que «no se puede afirmar que en la denominada jurisdicción voluntaria los jueces y tribunales no estén ejerciendo potestades jurisdiccionales (juzgar y hacer ejecutar lo juzgado), con independencia de que ulteriormente quepa sobre lo mismo otro proceso contradictorio, $y$, en consecuencia, esas potestades quedan amparadas por el artículo iI7.3 de la Constitución» (FJ $7^{\circ}$ ). Añade, además, que «las demás funciones, que el artículo II7.4 de la Constitución permite que una Ley atribuya a los jueces y tribunales en garantía de cualquier derecho, son aquéllas que, a

${ }^{40}$ En este sentido se han pronunciado Almagro Nosete, J. Derecho Procesal. Proceso Civil (con Cortés Domínguez, V., Gimeno Sendra, V. y Moreno CATenA, V.), cit., p. 77; DíeZ-Picazo GimeneZ, L. M., Régimen Constitucional del Poder Judicial, Civitas, Madrid I99I, p. 5I; JuAn SÁnCHEZ, R., Derecho Procesal Civil (con Ortells Ramos, M., Mascarell Navarro, M. J., Cámara Ruiz, J., Bonet Navarro, J., Bellido Penadés, R., Cucarella Galiana, L. A. y Martín Pastor, J.), Ed. Aranzadi, $3^{\text {a }}$ ed., Pamplona 2002, pp. 92-93; Gómez Colomer, J. L., Derecho Jurisdiccional (con Montero Aroca, J., Montón Redondo, A. y Barona Vilar, S.), vol. II (Proceso Civil), Ed. Tirant lo Blanch, I4 a ed., Valencia 2005, p. 859. Según este último autor, en los negocios voluntarios el Juez no ejerce jurisdicción porque no actúa irrevocablemente el derecho respondiendo a una pretensión -que, en su opinión, es inexistente al faltar la controversia entre las partes-, sino que, por el contrario, tutela y garantiza, por su auctoritas, derechos privados «o, como dicen nuestros textos legales máximos, ejerce en este caso el juez una función expresamente atribuida por la ley en garantía de un derecho (arts. II7.4 CE y 2.2 LOPJ)».

${ }^{4}$ La fijación de esta fecha inicial para el análisis de la juriprudencia del Tribunal Supremo, responde al interés por cotejar estas sentencias con los pronunciamientos que, en la misma época y sobre la misma materia, ha realizado el Tribunal Constitucional y que acabamos de sistematizar. 
diferencia de las denominadas de jurisdicción voluntaria, no comportan protección jurisdiccional de derechos e intereses legítimos, como en los supuestos de participación de jueces o magistrados en los Jurados de Expropiación Forzosa o en la Administración Electoral, en que aquéllos se incorporan a otras Administraciones del Estado por la garantía que su presencia en ellas confiere» $\left(\mathrm{FJ} 7^{\circ}\right)$.

Si bien, en nuestra opinión, la función primordial del Tribunal Supremo no es la de establecer el contenido y alcance de los preceptos constitucionales -más cuando en esta materia dicha delimitación se ha producido en contra de la doctrina constante del Tribunal Constitucional - es en esta sentencia, como ya ha quedado expuesto (vid. supra apartado III), en la que FERNÁNDEZ DE BUJÁN fundamenta su concepción «jurisdiccionalista» de los negocios de jurisdicción voluntaria judicial, al entender que en el art. II7.4 CE no tienen cabida «actos tan heterogéneos, de contenido tan diverso y de características procesales y finalidad tan diferente $»^{42}$. Es más, este autor mantiene que la exclusión de la jurisdicción voluntaria del elenco de funciones de competencia judicial relacionadas en el art. 2.2 LOPJ es prueba fehaciente de la intención del legislador de reconocer las teorías que defienden la naturaleza intrínsecamente jurisdiccional de esta institución ${ }^{43}$. Argumenta para ello que la omisión de referencia a esta institución en el art. 2.2 LOPJ — que, entiende, no es sino el desarrollo legislativo del art. II7.4 CE- tiene por finalidad implícita incluirla en el art. 2.I LOPJ y, por tanto, reconocer su carácter jurisdiccional ex art. II7.3 CE.

A nuestro juicio, el hecho de que el art. 2.2 LOPJ no recoja en su relación de funciones encomendadas al Juez la de la jurisdicción voluntaria no es, necesariamente, una intención manifiesta del legislador. Ciertamente, este número no recoge esta referencia como tampoco recoge, por ejemplo, la relativa a la llevanza de la instrucción penal. Además, a fortiori, tal interpretación podría ser tildada de inconstitucional, al menos para aquellos supuestos de jurisdicción voluntaria de homologación civil de las resoluciones y decisiones eclesiásticas sobre matrimonio canónico rato y no consumado (SSTC 93/1983, de 8 de noviembre $\left[\mathrm{FJ} 3^{\circ}\right.$ ] y $328 /$ I993, de 8 de noviembre [FJ $2^{\circ}$ ]) y para los procedimientos de adopción y acogimiento de menores (SSTC 93/1983, de 8 de noviembre [FJ $3^{\circ}$ ] y I24/2002, de 20 de mayo $\left[\mathrm{FJ}^{\circ}\right.$ ]]), respecto de los cuales el Tribunal Constitucional ya ha establecido que su fundamento se encuentra en el art. II7.4 de la Carta Magna y, por tanto, en el art. 2.2 LOPJ.

En conclusión de lo expuesto, se constata que en esta materia existe una importante divergencia sobre el contenido constitucional de los arts. II7.3 y II7.4 CE en algunos pronunciamientos del Tribunal Constitucional y del Tribunal Supremo; divergencia que repercute, en nuestra opinión, en la consideración de su naturaleza jurídica tengan éstos. Mientras que el primero estima que en los expedientes de jurisdicción voluntaria no existe auténtica jurisdicción, porque en ellos el Juez no juzga y hace ejecutar lo juzgado, el segundo afirma que en este tipo de asuntos el Juez sí ejerce la potestad jurisdiccional.

Sin ánimo de prejuzgar los posibles resultados de otros estudios, que confiamos realizar más adelante, en principio estimamos más atendible la doctrina mantenida por el primero de los dos órganos, y ello por dos razones: en primer lugar, porque el Tribunal Constitucional es el máximo intérprete de la Carta Magna, el órgano encargado de realizar la interpretación auténtica de la Constitución (arg. ex art. I LOTC); en segundo lugar,

${ }^{42}$ FERNÁNDEZ DE BUJÁN, A. La jurisdicción voluntaria, cit., pp. II4-II5; IDEM, «Jurisdicción voluntaria: sanción constitucional y propuesta de racionalización del sistema», en Actualidad Civil, núm. 37, 200I, p. I23I; IDEM, «La jurisdicción voluntaria: una reforma legislativa pendiente», en Estudios Jurídicos: Secretarios Judiciales, Vol. IV, 2002, p. 572.

${ }^{43}$ Cfr. FERNÁNDEZ DE BUJÁN, A., La jurisdicción voluntaria, loc. cit. 
porque el Tribunal Supremo se aferra a la concepción del Juez como una especie de «rey Midas» que, por estar imbuido de auctoritas, convierte en jurisdiccional todo lo que toca ${ }^{44}$; argumento éste que, en opinión de quien suscribe estas líneas, queda huérfano de adecuada fundamentación en la citada sentencia del Tribunal Supremo.

\section{La delimitación de la naturaleza jurídica de la Jurisdicción Voluntaria en el Anteproyecto de Ley de 2005: consideraciones críticas.}

I. Necesidad de una nueva regulación legal.

Pese a que si acudimos al Libro III de la LEC de $188 \mathrm{I}^{45}$ pudiera parecer que la jurisdicción voluntaria se halla perfectamente regulada y delimitada en el campo del Derecho civil (arts. I.825 a 2.I08 LEC de I88I) y en el campo del Derecho mercantil (arts. 2.IO9 a 2.I8I LEC de I88I), lo cierto es que la premisa de partida para toda reflexión en esta materia debe ser la constatación de que su regulación, con carácter general, resulta caótica, dispersa y anacrónica ${ }^{46}$, además de tener un contenido muy heterogéneo. En este último sentido, la existencia de actos de jurisdicción voluntaria se produce, según ha subrayado MUÑOZ ROJAS, fuera de los ámbitos legislados por la LEC de I88I, pudiendo ampliarse éstos a cuestiones tan dispares como los actos preparatorios del proceso laboral declarativo (arts. 76 y 77 LPL), la conciliación laboral (art. 50 LPL) e, incluso, la conciliación penal (art. 804 LECrim) $)^{47}$.

Todas estas razones han llevado a los autores y, entre ellos, al Profesor FERNÁNDEZ DE BUJÁN, a poner de manifiesto con reiteración la necesidad de acoger el modelo alemán y, por tanto, de que se apruebe una Ley de la Jurisdicción Voluntaria que contenga todos los supuestos que en el Derecho español tienen esta naturaleza, dándose cumplimiento además, de una vez por todas, a la Disposición Final I $8^{a}$ de la LEC de $2000^{48}$.

${ }^{44}$ En acertada expresión de AlloRIO, E., «Ensayo polémico sobre la “jurisdicción” voluntaria», cit., p. 34. Según éste, las tesis finalistas «al pretender descubrir una sustancia común a todas las actividades del Juez, jurisdiccionales en sentido estricto o voluntarias, negándose a admitir que las segundas le sean atribuidas por el legislador por puras razones de oportunidad contingente, extrañas a la sustancia o eficacia de las actividades mismas, hacen del juez una especie de Midas, que con su tacto haría "jurisdiccional" o "procesal" todo aquello sobre lo cual pusiese él su mano, aunque en sí no lo fuese».

${ }^{45}$ Aún vigente conforme a la Disposición Derogatoria Única I.I ${ }^{\mathrm{a}}$ de la Ley I/2000, de 7 de enero, de Enjuiciamiento Civil.

${ }^{46}$ Así lo han puesto de manifiesto, por ejemplo, Gómez OrbaneJA, E., y Herce QuemadA, V., Derecho Procesal Civil, Tomo II, Artes Gráficas y Ediciones, 6ª ed., Madrid i969, p. 384; RAMOS MÉNDEZ, M., La jurisdicción voluntaria en negocios de comercio, cit., pp. 23-34.

${ }^{47}$ Así, MuÑoz RoJAS, T., «Sobre la jurisdicción voluntaria», en Actualidad Civil, XXXIX, I990, pp. 577-585; especialmente pp. 580-58I.

${ }^{8}$ Cfr. FERNÁNDEZ DE BUJÁN, A., «Jurisdicción voluntaria: naturaleza y diferencias de procedimiento con la jurisdicción contenciosa», en Actualidad Civil, núm. 36, 200I, p. I.278; IDEM, La jurisdicción voluntaria, cit., p. I7; IDEM, «La jurisdicción voluntaria: una reforma legislativa pendiente», cit., p. 538; IDEM, «La reforma de la jurisdicción voluntaria: problemas, interrogantes, soluciones», cit., pp. I-2. 
2. El concepto de potestad jurisdiccional en sentido amplio.

Como se desprende del primero de los artículos del Anteproyecto de Ley de Jurisdicción Voluntaria de octubre de $2005^{49}$ - que fija un ámbito de aplicación de la futura ley sustancialmente idéntico al fijado hace ya más de un siglo por el art. I.8II LEC ı88I, aún vigente-, con la expresión «jurisdicción voluntaria» se hace referencia a aquellos procedimientos en los que un particular solicita la intervención de un tribunal, o éste interviene de oficio o a instancia del Ministerio Fiscal, sin que exista una contienda o conflicto de intereses relevante con otras personas.

Por lo que respecta a la naturaleza jurídica de la institución, si bien no hallamos ninguna mención a ella en el articulado del Anteproyecto, se señala en la Exposición de Motivos que «no es la jurisdicción voluntaria una actividad administrativa, cuya titularidad se atribuye a los Juzgados y Tribunales, sino que la protección, gestión o administración de derecho o intereses privados que se atribuye a los Jueces, supone un ejercicio de la potestad jurisdiccional en sentido amplio, en atención al carácter indisponible de los derechos o intereses legítimos tutelados, a la interrelación entre intereses particulares con intereses generales o sociales, al carácter tutelar, constitutivo, preventivo, ejecutivo o complementador respecto a la posición de menores, incapacitados, personas con discapacidad o desvalidos, o bien se justifica, en determinados supuestos, en atención a la especial garantía que supone la intervención judicial» (apartado II).

Dado el casuismo y la heterogeneidad que derivan de la enumeración anterior, interesa determinar a las claras qué entiende el Anteproyecto por «potestad jurisdiccional en sentido amplio»; cuestión de la que también se ocupa la misma Exposición de Motivos. Así, en primer lugar, como núcleo esencial del concepto, esta potestad incluye el «dirimir los conflictos a través del proceso, con todas las garantías propias de la actividad procesal». En segundo lugar, y como parte también del contenido de las facultades atribuidas por el art. II7.3 CE a Juzgados y Tribunales, incluye el «otorgar tutela jurídica fuera del proceso, con respeto a las fundamentales garantías del procedimiento, en asuntos relativos a menores, personas con discapacidad, incapacitados, desvalidos, ausentes, intereses generales, públicos o sociales, restricción de derechos fundamentales o en conflictos no especialmente relevantes, mediante la aplicación de derecho objetivo». Por último, se adicionan a esas funciones «aquellas otras que en garantía de derechos conforme se establece en el artículo II7.4 de la Constitución, parece razonable atribuir o mantener en la órbita de la competencia jurisdiccional, como es doctrina del Tribunal Constitucional» (apartado I).

Completando lo anterior, una vez fijado este contenido amplio de la potestad jurisdiccional, prosigue la Exposición de Motivos: «cabría argumentar a favor de la consideración global de la jurisdicción voluntaria en el marco del artículo II7.3, que el artículo II7.4 de la Constitución sólo habla de garantía de derechos, y es evidente que a través del procedimiento de jurisdicción voluntaria pueden tutelarse no sólo derechos, sino también intereses legítimos, objeto ambos de tutela judicial efectiva, a través del cauce del II7.3 de la Constitución» (apartado II).

$\mathrm{Si}$, como bien se precisa en el texto, «doctrina y jurisprudencia están de acuerdo en que es hora ya de que la jurisdicción voluntaria deje de ser un campo de experimentación del legislador» (apartado IV de la Exposición de Motivos), no entendemos cómo el redactor

\footnotetext{
${ }^{49}$ Concretamente, dispone este precepto: «Se considerarán expedientes de jurisdicción voluntaria todos aquellos en que sea necesaria o se solicite la intervención de un tribunal sin estar empeñada ni promoverse contienda alguna entre las partes conocidas y determinadas, sin perjuicio de que en ellos pueda suscitarse oposición conforme a lo regulado en esta Ley».
} 
del Anteproyecto no se ha pronunciado claramente sobre la naturaleza jurídica de esta institución milenaria. En nuestra opinión, establecer un concepto tan amplio y farragoso de potestad jurisdiccional —aunando los arts. II7.3 y 4 CE para conseguir la inclusión en él de diversos expedientes voluntarios - supone tanto como renunciar a cualquier intento de esclarecer, de una vez por todas, la verdadera naturaleza jurídica de la jurisdicción voluntaria. Además, acudir a dicho concepto vendrá a actualizar el cajón de sastre que ha sido la jurisdicción voluntaria en nuestro ordenamiento jurídico en los últimos ciento veinte años, máxime si tenemos en cuenta que las disposiciones del procedimiento general de jurisdicción voluntaria, establecido en el Capítulo III del Título I del Anteproyecto (arts. 8 a 23), «se aplicarán a todas las actuaciones de jurisdicción voluntaria reguladas en ésta u otras leyes, en lo que no se opongan a las normas que especialmente regulen las actuaciones de que se trate» (art. 8 ALJV).

En nuestro criterio, es ya momento de que el legislador afronte directamente la determinación precisa de la naturaleza de la jurisdicción voluntaria, ya que entendemos que ésta es la única forma de fijar por fin su sede científica y de establecer su contenido y sus límites. De hecho, existen motivos de peso para que el legislador supere el concepto de potestad jurisdiccional en sentido amplio que aplica a los expedientes de jurisdicción voluntaria.

En primer lugar, como bien se reconoce en la propia Exposición de Motivos del Anteproyecto, no puede afirmarse que el núcleo esencial de la jurisdicción voluntaria sea «dirimir conflictos a través del proceso» puesto que, en estos procedimientos «no existen, en general, posiciones contrapuestas, a priori, de personas enfrentadas» (apartado II). A este respecto también es claro el art. I ALJV, al establecer que en los expedientes de esta clase no está desempeñada ni se promueve contienda alguna entre partes conocidas; razón ésta por la cual a lo largo del Anteproyecto se habla de interesados y no de partes. En tal sentido, téngase en cuenta que, como ha afirmado MORENO CATENA, «cuando en actuaciones ante los tribunales de justicia no aparecen las dos posiciones de parte podemos decir seguramente que nos encontramos ante una actividad judicial, pero no jurisdiccional; es el caso de los actos de jurisdicción voluntaria del Libro III de la LEC de I88I. De no existir litigio estaremos ante actuaciones judiciales, pero nunca ante un verdadero proceso ${ }^{5 \circ}$ en donde los jueces ejercen la actividad jurisdiccional.

En segundo lugar, por lo que respecta a la consideración de la jurisdicción voluntaria como institución garante de la tutela judicial fuera del proceso stricto sensu - $y$ por esa razón residenciada en sentido amplio en el art. II7.3 CE-, hay que señalar que es doctrina constante del Tribunal Constitucional la proyección del art. 24.I CE a las funciones referidas en el art. II7.4 CE y, en el caso de que un Juez en garantía de un derecho decidiera de forma manifiestamente arbitraria o irrazonada, resultaría lesionado el derecho a la tutela efectiva, al quedar dificultadas gravemente las posibilidades de defensa, tanto en un posterior control jurisdiccional de la actuación judicial previa en vía ordinaria, como, en último término, ante el propio Tribunal Constitucional ${ }^{\mathrm{5}}$. En lo que ahora nos interesa, como ya se ha señalado en este trabajo (vid. supra apartado V), nuestro Tribunal Constitucional ha llegado a considerar desde bien temprano que la regulación procedimental de los actos de jurisdicción voluntaria, incluibles en el art. II7.4 CE, no desconoce la tutela judicial efectiva del art. 24.I CE, al haber previsto el legislador un cauce

\footnotetext{
${ }^{50}$ Moreno Catena, V., Derecho Procesal Civil. Parte general (con Cortés Domínguez, V. y Gimeno SENDRA, V.), Ed. Colex, 3 ffi ed., Madrid 2000, p. 84.

${ }^{51}$ SSTC 62/1982, de I5 de octubre (FJ 2 ${ }^{\circ}$.b); 9/1983, de 2I de febrero (FJ 4º); 93/i983, de 8 de noviembre (FJ $3^{\circ}$ ); y II5/I987, de 7 de julio (FJ I ${ }^{\circ}$ ); 85/1994, de I4 de marzo (FJ $3^{\circ}$ ). Vid., igualmente, SÁnCHEZ BARRILAO, J. F., Las funciones no jurisdiccionales de los jueces en garantía de derechos, Ed. Civitas, Madrid 2002, pp. I85-188.
} 
procesal «para el supuesto de oposición que permita la efectividad del mencionado derecho fundamental» ${ }^{52}$ (STC 93/1983, de 8 de noviembre [FJ $\left.3^{\circ}\right]$ ). No se trata en estos casos de que las funciones de jurisdicción voluntaria - funciones judiciales en garantía de derechos distintas a la potestad jurisdiccional — no contengan el derecho de los ciudadanos a la tutela judicial efectiva; lo que ocurre es que dicha tutela queda postergada a un ulterior momento, en que se da la posibilidad de un proceso contradictorio donde el Juez sí actúe juzgando y haciendo ejecutar lo juzgado.

Por último, el argumento conforme al cual la jurisdicción voluntaria no se puede residenciar en el art. II7.4 CE porque en éste sólo se habla de garantía de derechos mientras que con ella también pueden tutelarse intereses legítimos no nos parece del todo adecuado. Y ello porque, en nuestra opinión, cuando los constituyentes redactaron el art. II7.4 CE no tenían la intención de excluir de su ámbito los intereses legítimos. Aunque en futuros trabajos llevemos a cabo un estudio más pausado sobre la génesis de dicho precepto constitucional que nos permita fundamentar cabalmente este argumento, puede sostenerse de acuerdo con la doctrina constitucional acerca de la tutela judicial efectiva de los expedientes de jurisdicción voluntaria. Como ya hemos puesto de manifiesto (vid. supra nota 39), el Tribunal Constitucional ha establecido que, con independencia de los cauces procesales concretos — sean éstos de naturaleza contenciosa o voluntaria-, lo fundamental es garantizar que el sujeto «ha disfrutado de la posibilidad real de defender sus derechos e intereses legítimos mediante los medios de alegación y de prueba pertinentes» (SSTC 76/1990, de 26 de abril [FJ 6º ] 298/1993, de I8 de octubre [FJ 6] y II4/I997, de I6 de junio $\left[\mathrm{FJ} 2^{\circ}\right.$, entre otras). Aunque el concepto de interés legítimo — se ha de tratar de un interés personal reconocido y protegido por el Derecho- sea más amplio que el de derecho, no nos parece irrazonable mantener, de acuerdo con esta doctrina, la suficiencia del interés legítimo como título de legitimación para actuar en vía procesal ex art. II7.4 CE.

3. Superación del concepto y naturaleza jurídica.

Llegados a este punto, creemos que, o se delimita más precisamente el concepto establecido en el Anteproyecto de potestad jurisdiccional en sentido amplio — con lo que dejarían de considerarse así determinados expedientes de jurisdicción voluntaria- o, en el caso de mantenerse, se perpetuará esta institución como un cajón de sastre, reduciéndose toda diferencia entre la jurisdicción contenciosa y la jurisdicción voluntaria a una simple cuestión de nomen iuris.

Pese a que la Exposición de Motivos sigue apegada a la tradición jurídica y a la práctica instaurada por el Libro III de la LEC de I88I, lo cierto es que pareciera que el espíritu del Anteproyecto tuviera una determinada concepción no jurisdiccional de la naturaleza jurídica de la institución.

${ }^{52}$ El cauce procesal pertinente en la legislación vigente es el art. I.8I7 LEC de I88I en el que se prevé que si al expediente voluntario se hiciera oposición por alguien con interés en el asunto éste se hará contencioso. Sin embargo, esta situación sufrirá una modificación sustancial en la futura ley. La novedad consistirá en que, salvo previsión legal expresa, la formulación de oposición en el expediente voluntario por algún interesado en el asunto no lo convertirá en contencioso, ni impedirá la tramitación del mismo hasta su resolución. Eso sí, no adquiriendo en ningún caso fuerza de cosa juzgada lo resuelto en expediente de esta naturaleza (art. I8. I ALJV), nada obsta a que los interesados, finalizado el expediente, promuevan el proceso declarativo que corresponda para la defensa de sus derechos (art. I8.2 ALJV), quedando a salvo de esta manera su derecho a la tutela judicial efectiva $e x$ art. 24.I CE. 
En efecto, el art. 5 ALJV introduce importantes novedades respecto de la legislación vigente cuando atribuye competencias en esta materia a los Secretarios Judiciales $^{53}$. Realizada por su apartado primero una enumeración numerus apertus ${ }^{54}$, establece en su apartado segundo una regla general conforme a la cual, para los expedientes no regulados en la citada ley, se confiará a los Secretarios Judiciales la tramitación y resolución definitiva de aquéllos que no tengan por objeto la condición o estado civil de la persona o asuntos de Derecho de familia, que no afecten a derechos y libertades fundamentales o no tengan por objeto materias sobre las que los interesados no puedan disponer libremente. Parece razonable entender entonces que si, de lege ferenda, la competencia sobre la tramitación y resolución de los expedientes se atribuye con carácter general a los Secretarios Judiciales, la jurisdicción voluntaria no puede tener naturaleza jurisdiccional por cuanto éstos no «juzgan» ni «hacen ejecutar lo juzgado».

Igualmente, es posible que por razones históricas o de política legislativa se atribuya a los jueces la resolución de determinados expedientes voluntarios (i.e., aquéllos que versen sobre el estado civil, derecho de familia, derechos fundamentales o materias indisponibles), pero en esos supuestos no ejercerán su potestad jurisdiccional sino una «actividad gubernativa y típicamente administrativa»" Tanto es así que, por ejemplo, un expediente de adopción, cuya tramitación y resolución corresponde al «Juzgado de Primera Instancia de la sede de la Entidad Pública que tenga encomendada la protección de menores y, en su defecto, el del domicilio del adoptante» (art. 55 ALJV) por ser relativo a un supuesto de Derecho de familia, en los casos de adopción internacional — para nada anecdóticos en la realidad jurídica actual- se regirá por lo previsto en el art. 9.5 CC (ex art. 67 ALJV), que, como es bien sabido, dispone que «los Cónsules españoles tendrán las mismas atribuciones que el Juez, siempre que el adoptante sea español y el adoptando esté domiciliado en la demarcación consular». De ello se deduce, necesariamente, el carácter administrativo de este expediente de jurisdicción voluntaria — que, además, corresponde a aquéllos que están exceptuados del conocimiento por parte de los Secretarios Judiciales- ya que no se podrá argumentar, en ningún caso, que en estos concretos supuestos el Cónsul español está

${ }^{53}$ Esta redistribución competencial trae causa, por ejemplo, de la recomendación R (I986) I2, de I6 de septiembre, del Comité de Ministros del Consejo de Europa, relativa a ciertas medidas dirigidas a prevenir y reducir la sobrecarga de trabajo de los tribunales, o de la reforma introducida en el art. 456.3.b) LOPJ por la Ley I9/2003, de 23 de diciembre, que cita expresamente entre las facultades que las leyes procesales pueden prever que tenga el Secretario: «la jurisdicción voluntaria, asumiendo su tramitación y resolución, sin perjuicio de los recursos que quepa interponer». Esta necesidad también ha sido puesta de manifiesto por la doctrina. Vid., por ejemplo, MUÑOZ ROJAS, T., «Sobre la jurisdicción voluntaria», cit., p. 585; PEDRAZ PENALVA, E., «La nueva Secretaría Judicial», en Revista del Poder Judicial, I992, pp. 85-IO8; FERNÁNDEZ DE BUJÁN, A., La jurisdicción voluntaria, cit., pp. I4I-I62, con especial consideración al ámbito de atribución de competencias a los Secretarios Judiciales en pp. I59-I60; IDEM, «Jurisdicción voluntaria: sanción constitucional y propuesta de racionalización del sistema», cit., pp. I323-I337, con especial consideración dicho ámbito en pp. I335-I336; IDEM, «La jurisdicción voluntaria: una reforma legislativa pendiente», cit., pp. 574-590, con especial consideración a las funciones de los Secretarios Judiciales en p. 589; IDEM, «La reforma de la jurisdicción voluntaria: problemas, interrogantes, soluciones», cit., pp. 5-7.

${ }^{54}$ Enumeración que incluye veintiocho expedientes de esta naturaleza, entre los que se incluyen, por ejemplo, los de conciliación, declaración de ausencia y fallecimiento, deslinde y amojonamiento, consignación judicial, subastas judiciales no ejecutivas, presentación, adveración y protocolización de testamentos ológrafos, nombramiento de interventor o liquidador, robo, hurto, extravío o destrucción de título al potador y de letras de cambio, cheque o pagaré o el extravío, sustracción o destrucción del conocimiento de embarque. Como se puede observar, se incluyen supuestos de jurisdicción voluntaria en materia de personas, derechos reales, sucesiones, Derecho mercantil y Derecho marítimo.

${ }^{55}$ MuÑOZ RoJAS, T., «Sobre la jurisdicción voluntaria», cit., p. 58I. Este argumento se puede deducir también de la doctrina constitucional mantenida, entre otras, por las SSTC 93/1983, de 8 de noviembre $\left(\mathrm{FJ} 3^{\circ}\right.$ ) y I24/2002, de 20 de mayo $\left(\mathrm{FJ} 4^{\circ}\right)$. 
habilitado para ejercer la potestad jurisdiccional, juzgando y haciendo ejecutar lo juzgado, puesto que ésta se atribuye en exclusiva a jueces y magistrados ${ }^{56}$.

\section{Conclusiones.}

A pesar de la heterogeneidad y la dispersión normativa que existe en la actualidad respecto de la regulación positiva de la jurisdicción voluntaria, hemos constatado que existen dos grandes problemas fundamentales para determinar su naturaleza jurídica, jurisdiccional o administrativa. De una parte, el problema consiste en determinar si nos hallamos ante auténtica jurisdicción ${ }^{57}$, para lo cual hay que comenzar por distinguir entre Jurisdicción y Administración -la CE sólo reconoce la existencia de tres potestades: la legislativa, la ejecutiva y la judicial; y es por ello que, en nuestra opinión, la jurisdicción voluntaria no constituye un tertium genus entre Jurisdicción y Administración, sino que, al contrario, debe poder encuadrarse en uno de estos conceptos-; y de otra, si es posible predicar de sus providencias la fuerza de cosa juzgada. En espera de un estudio profundo sobre el tema, es posible adelantar, siquiera sea de manera provisional, que el problema de la naturaleza jurídica, auténticamente jurisdiccional o simplemente administrativa, depende, en última instancia, de la concepción que se mantenga de la Jurisdicción y, en concreto, de si se estima o no que el elemento litigioso o contencioso y el efecto de cosa juzgada de las resoluciones son características esenciales de la idea de Jurisdicción.

Pese a todo, tres extremos nos parecen suficientemente claros. Por una parte, desde un punto de vista histórico, no suscita grandes dudas el hecho de que la jurisdicción voluntaria nació como la ficción de un proceso contencioso, a fin de dotar de certeza a determinados actos y negocios. Esta ficción se ha consolidado a lo largo de los siglos como uno de los cometidos de la Administración de Justicia, de ahí que en la actualidad se halle regulada en la legislación procesal civil. Por otra parte, cuando el art. II7.3 CE dice que la potestad jurisdiccional consiste en juzgar y hacer ejecutar lo juzgado, está ofreciendo, al menos de forma primaria, una visión contenciosa de la jurisdicción, como ha entendido la STC 93/1983, de 8 de noviembre (FJ $3^{\circ}$ ). En consecuencia se puede entender que la atribución de los negocios de jurisdicción voluntaria al Poder Judicial no está constitucionalmente garantizada frente al legislador, por mucho arraigo que tenga en la tradición jurídica española. Por último, la actuación de los órganos públicos en los expedientes de jurisdicción voluntaria estriba en innovar, desarrollar, modificar o extinguir, sin contradicción ni oposición actual, determinadas relaciones o situaciones jurídicas sustantivas y, por tanto, en nada se altera la índole de estos procedimientos por el hecho de que su conocimiento se confiera a órganos no jurisdiccionales. Existe, es cierto, una contradicción u oposición potencial, pero ésta no afecta a la autoridad pública competente

\footnotetext{
${ }^{56}$ Así lo entiende también ORTELLS RAMOS, M., «La competencia judicial en la Ley de reforma de la adopción», en Justicia, núm. 4, I988, pp. 835-857 concluyendo que «una atribución de esta potestad (jurisdiccional, se entiende) no puede entenderse implícitamente hecha por el artículo 9.5.III del CC, dado que esta interpretación del artículo no sería conforme a la Constitución (art. 5.I LOPJ) por infringir la norma de exclusiva atribución de la potestad jurisdiccional a los órganos jurisdiccionales» (p. 838).

${ }^{57}$ Sobre las diversas definiciones de la función jurisdiccional existentes en sede doctrinal, vid., sin ánimo de exhaustividad, SERrA DomíngueZ, M., Estudios de Derecho Procesal, cit., pp. 20-II7; Gimeno Sendra, V., Fundamentos de Derecho Procesal, Ed. Civitas, Madrid i98I, pp. 2I-I26; GUASP Delgado, J. y Aragoneses Alonso, P., Derecho Procesal Civil, Tomo I, cit., pp. 89-II3; Montero Aroca, J., Derecho Jurisdiccional (con Gómez Colomer, J. L., Montón REdondo, A. y BARONA Vilar, S.), Vol. I (Proceso civil), cit., pp. 37-40.
} 
para la resolución del expediente voluntario. En este sentido, como bien se recoge en el Anteproyecto, «la formulación de oposición por algún interesado no hará contencioso el expediente ni impedirá la tramitación de éste hasta su efectiva resolución» (art. I8.2 ALJV). Además, lo resuelto en el expediente, al no tener efectos de cosa juzgada material, no obstará para que pueda «promoverse sobre el mismo asunto proceso declarativo por el procedimiento que corresponda» (art. I8.I ALJV), en donde el Juez competente tendrá conocimiento del asunto, ahora sí, ejerciendo su potestad jurisdiccional ex art. II7.3 CE. 